\title{
Eksplorasi Etnomatematika pada Seni Batik Madura dalam Pembelajaran Geometri
}

\author{
Tri A. M. Sari ${ }^{1 *}$, Alkaromah N. Sholehatun', Syifa A. Rahma ${ }^{2}$, Rizky B. Prasetyo ${ }^{2}$ \\ ${ }^{1}$ Pendidikan Matematika, Universitas Muhammadiyah Purworejo, Indonesia \\ ${ }^{2}$ Pendidikan Matematika, Universitas Muhammadiyah Jakarta, Indonesia \\ *ardiliamaya3@gmail.com
}

\begin{tabular}{|c|c|}
\hline Article Info & Abstract \\
\hline $\begin{array}{l}\text { Received } \\
13 \text { October } 2021\end{array}$ & $\begin{array}{l}\text { Batik is an extraordinary work of art that must be preserved, it can be } \\
\text { through formal or non-formal education. So far, cultural products are } \\
\text { not always recognized for their usefulness in the scope of formal } \\
\text { education. This study aims to map mathematical concepts on Madura }\end{array}$ \\
\hline $\begin{array}{l}\text { Revised } \\
08 \text { November } 2021\end{array}$ & $\begin{array}{l}\text { batik that can be integrated in mathematics learning. This research is } \\
\text { a qualitative descriptive study with an ethnographic approach by } \\
\text { conducting observations and interviews, then a literature study is }\end{array}$ \\
\hline $\begin{array}{l}\text { Accepted } \\
11 \text { November } 2021\end{array}$ & $\begin{array}{l}\text { carried out related to the geometry. The instrument in this study is a } \\
\text { human instrument, the researcher is directly related to the research } \\
\text { and acts as a data collector. The data were analyzed by making codes }\end{array}$ \\
\hline Keywords & $\begin{array}{l}\text { which were then reduced based on the concepts and learning materials } \\
\text { of geometry. The results of this study in the form of mathematical } \\
\text { concepts contained in the Madura Batik motif are: straight line, }\end{array}$ \\
\hline $\begin{array}{l}\text { Batik Madura, } \\
\text { Ethnomathematics, } \\
\text { Geometry }\end{array}$ & $\begin{array}{l}\text { curved line, parallel line, symmetry, point, angle, triangle, circle, } \\
\text { rhombus and similarity concept. Some Madura batik motifs can be } \\
\text { used as a medium to introduce mathematical concepts such as } \\
\text { concepts in geometry so that it is expected to make it easier to } \\
\text { understand abstract mathematical concepts. }\end{array}$ \\
\hline
\end{tabular}

How to Cite:

Sari, T. A. M., Sholehatun, A. N., Rahma, S. A., \& Prasetyo, R. B. (2021). Eksplorasi Etnomatematika pada Seni Batik Madura dalam Pembelajaran Geometri. Journal of Instructional Mathematics, 2(1), 71-77.

\section{PENDAHULUAN}

Batik dan Indonesia adalah dua entitas yang seakan tertanam (Rakhmawati, 2016). Ragam suku dari ribuan pulau dengan latar geografi, demografi, dan interaksi sosial melahirkan situs-situs budaya yang beraneka ragam. Bahkan dalam pergaulan internasional melalui United Nations Educational, Scientific and Cultural Organisation (UNESCO) bahwa batik diakui dan ditetapkan sebagai salah satu situs warisan budaya milik Indonesia yag ditetapkan (Antara, 2009). Selama ini batik diletakkan sebagai bagian budaya pada beberapa daerah seperti Solo, Yogyakarta, Pekalongan (Prayitno, 2020; Lestari \& Syafii, 2019; Saraswati, Iriyanto \& Putri, 2021). Ternyata motif batik di Indonesia lebih beragam dari yang selama ini dikenal. Di Jawa Timur, tepatnya di Pulau Madura memiliki kekayaan situs budaya dalam bentuk batik. Madura merupakan pulau kecil di Jawa Timur yang memiliki budaya, ciri khas yang berbeda dengan daerah yang lain. Seperti pada corak dan seni baju batik yang dihasilkan berupa motif batik madura yaitu motif berserat (Zayyadi, 2017). Motif-motif dalam Batik terkadang menunjukkan beragam konsep matematika khususnya pada konsep geometri (Suciaty dkk., 2019). Hal ini 
menandakan bahwa konsep matematika terutama konsep geometri, secara tidak langsung telah mengakar pada masyarakat. Ini juga tentu terjadi di masyarakat Madura. Konsep matematika yang diaplikasikan pada lingkungan sosial budaya dan tertanam secara turun temurun ini harusnya menjadi salah satu modal awal bagi pembelajar matematika untuk dimanfaatkan oleh masyarakat. Hanya saja pengetahuan tersebut harus diasimilasikan, dikonstruksikan dan dikembangkan pada proses belajar matematika sehingga nantinya akan menghasilkan pengetahuan matematika yang utuh, tertanam dan lebih bermakna.

Tuntutan kurikulum dan target kompetensi dasar yang harus dipenuhi oleh guru pada saat ini menyebabkan pembelajaran matematika menjadi kurang bermakna. Hal ini terlihat bahwa pemahaman pada esensi konsep matematika serta bagaimana mengaplikasi dan dari mana sumbernya masih relatif kurang. Bahkan siswa relatif sering belum mengenal budaya setempat yang sekiranya dapat diaplikasikan dalam pembelajaran matematika mereka. Di sisi lain, pembelajaran matematika juga kadang lebih banyak menekankan pada hal-hal yang bersifat kontekstual, tetapi di suatu daerah tertentu sementara tidak falimiar di daerah lain. Ini bisa diperiksa pada buku teks belajar matematika yang digunakan oleh siswa. Padahal, kehadiran matematika yang bernuansa budaya, atau sebaliknya, yang biasa dikenal dengan etnomatematika, akan memberikan konstribusi besar terhadap pembelajaran matematika. Di sini, pendidikan formal merupakan institusi sosial yang berbeda dengan yang lain sehingga memungkinkan terjadinya sosialisasi antar budaya. Dikatakan pula bahwa semua pendidikan matematika formal adalah suatu proses interaksi budaya dan setiap siswa mengalami berbagai konflik budaya dalam proses tersebut. Ide-ide matematika yang muncul secara alami, melalui pengetahuan dan pandangan suku atau kelompok masyarakat tertentu ataupun individu tertentu tanpa melalui suatu pendidikan formal. Hal ini dikonfirmasi oleh Kamaruddin (2015) menyatakan bahwa konsep-konsep matematika yang dijumpai pada pemukiman taneyan lanjang dan ukiran Madura, itu merupakan hasil kebudayaan yang ada pada masyarakat Madura.

Menurut Rosa \& Orey (2011), proses pembelajaran matematika akan berjalan dengan baik ketika seorang guru dalam mengajarnya mengkaitkan dengan proses interaksi sosial dan budaya melalui dialog, bahasa, melalui representasi makna simbolik dalam matematika. Lebih lanjut, D'Ambrosio (2004) mengatakan bahwa pengajaran matematika bagi setiap orang harusnya disesuaikan dengan budayanya. Untuk itu diperlukan keterhubungan antara konteks matematika di luar sekolah dengan matematika sekolah. Salah satu cara yang dapat digunakan adalah dengan memanfaatkan pendekatan etnomatematika sebagai awal dari pengajaran matematika formal yang sesuai dengan tingkat perkembangan siswa yang berada pada tahapan operasional konkret (Richardo, 2017). Hal yang sama dikemukakan oleh Shirley (2008) bahwa kehadiran matematika yang bernuansa budaya akan memberikan kontribusi yang besar terhadap matematika sekolah, karena sekolah merupakan institusi sosial yang berbeda dengan yang lain sehingga memungkinkan terjadinya sosialisasi antara beberapa budaya. Peran budaya akan mempengaruhi perilaku individu dan mempunyai potensi besar pada perkembangan pemahaman individual, termasuk pembelajaran matematika (Bishop, 1991).

Melalui penelitian ini diharapkan pengetahuan tentang matematika tidak hanya pada pendidikan formal saja tetapi juga bisa menjadi pembelajaran yang menekankan pada aspek sosial budaya masyarakat sekitar. Di sisi lain, nilai-nilai 
budaya lokal dapat menjadi media dalam pembelajaran matematika. Berdasarkan hal tersebut, maka penelitian ini dilakukan untuk mengeksplorasi konsep-konsep matematika yang terdapat pada motif batik madura dalam hubungannya dengan geometri. Hasil studi ini bisa digunakan sebagai jembatan untuk menjelaskan konsep-konsep geometri kepada masyarakat madura di samping melestarikan warisan leluhur yang memiliki nilai karya seni luar biasa jangan sampai diakuisisi oleh negara lain.

\section{METODE PENELITIAN}

Dalam penelitian ini, peneliti menggunakan penelitian deskriptif kualitatif dengan menggunakan pendekatan etnografi. Etnografi merupakan pendekatan empiris dan teoritis yang digunakan untuk menggambarkan, menjelaskan dan menganalisis unsur kebudayaan masyarakat atau suku bangsa (Arwanto, 2017). Pendekatan ini memusatkan usaha untuk mampu mengorganisasikan budaya sekitar dalam pikiran mereka dan mampu menerapkan ke dalam proses pembelajaran matematika.

Instrumen dalam penelitian ini adalah human instrument, yaitu peneliti berperan langsung sebagai instrumen utama yang tidak digantikan orang lain. Dalam hal ini, peneliti berhubungan langsung dengan penelitian dan berperan sebagai pengumpul data melalui pengumpulan data pustaka, wawancara, observasi dan dokumentasi.

Pengumpulan data dilakukan dengan melaksanakan wawancara kepada seseorang yang paham terhadap situasi obyek penelitian. Kemudian data dianalisis setelah membuat trakskrip hasil wawancara tersebut. Hasil traskrip yang diperoleh kemudian direduksi. Peneliti membuat reduksi data dengan cara memilah semua data yang sesuai dengan kebutuhan peneliti. Koding-koding yang direduksi dikelompokan berdasarkan konsep dan materi pembelajaran geometri. Selanjutnya data akan disajikan baru kemudian dianalisis dan disimpulkan. Kesimpulan ini merupakan dari hasil jawaban terhadap pertanyaan penelitian yang diteliti.

\section{HASIL DAN PEMBAHASAN}

Hasil dari penelitian ini berupa deskripsi dari beberapa motif khas pada Batik Madura yang mengandung nilai-nilai matematis. Beberapa motif pada Batuk Madura ini mengandung beberapa konsep matematika. Konsep-konsep matematika tersebut seperti konsep geometri.

\section{Deskripsi tentang Batik Madura}

Berdasarkan hasil analisis data, secara visual bahwa motif batik memiliki banyak bentuk geometri dengan kehadiran garis-garis, bentuk bidang datar, titik, dan cekungan. Di Madura juga terdapat jenis batik pedalaman bergaya klasik dengan ornamen utama berwarna gelap. Salah satu motif batik di madura adalah motif leres atau motif parang pada batik jawa (Suminto, 2015). Itu merupakan motif batik pedalaman yang mengedepankan garis melintang yang simetris, selaras dengan yang biasa ditemukan pada Batik Solo, Batik Yogyakarta dan Batik Pekalongan. Meski begitu, tema batik tergolong unik karena cenderung menampilkan warnawarna berani seperti biru, kuning, merah, hijau daun. Letak potensi produk budaya adalah pada kain batik madura itu sendiri. Secara keseluruhan motif batik Pulau Madura adalah tumbuhan, hewan atau kombinasi keduanya. 
Etnomatematika dalam penelitian ini adalah hasil aktivitas suatu masyarakat yang di dalamnya terdapat konsep-konsep matematika yang kadang belum disadari oleh masyarakat itu sendiri (Alghadari \& Son, 2018). D'Ambrosio (2001) menjelaskan bahwa tujuan dari etnomatematika adalah untuk mengakui bahwa ada cara-cara berbeda dalam melakukan matematika dengan mempertimbangkan pengetahuan matematika akademik yang dikembangkan oleh berbagai sektor masyarakat serta dengan mempertimbangkan modus yang berbeda di mana budaya yang berbeda merundingkan praktik matematika mereka (cara mengelompokkan, berhitung, mengukur, merancang bangunan atau alat, bermain dan lainnya). Etnomatematika memiliki pengertian yang lebih luas dari sekedar ethno (etnik), etnomatematika diartikan sebagai antropology budaya dari matematika dan pendidikan matematika (Arwanto, 2017).

Melalui gagasan etnomatematika, masyarakat bisa memperkaya pengetahuan terkait matematika yang ada di sekitarnya. Dengan demikian, sebagai hasil dari sejarah budaya, matematika dapat memiliki bentuk yang berbeda-beda dan berkembang sesuai dengan perkembangan masyarakat. Dengan demikian, dapat dikatakan bahwa terdapat konsep-konsep matematika yang dipraktikkan dalam kehidupan sehari-hari. Diantaranya adalah konsep geometri yang muncul pada seni budaya batik.

\section{Konsep-konsep Matematika}

Motif Batik Madura dapat dijadikan media untuk memperkenalkan konsep-konsep matematika seperti konsep-konsep geometri sehingga mempermudah dalam memahami konsep matematika yang bersifat abstrak antara lain adalah garis lurus, garis lengkung, garis sejajar, simetri, titik, sudut, persegi panjang, segitiga, lingkaran, jajargenjang dan konsep kesebangunan.

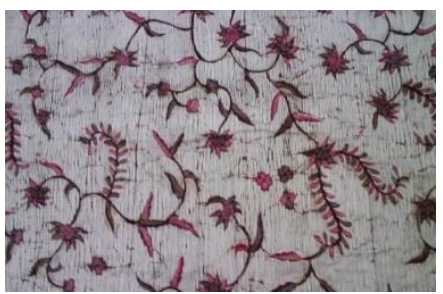

(a)

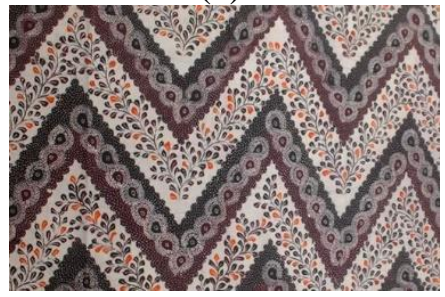

(d)

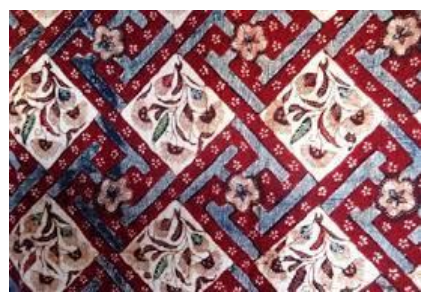

(b)

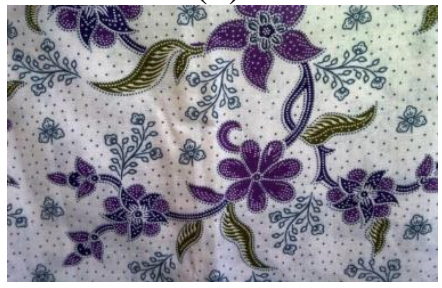

(e)

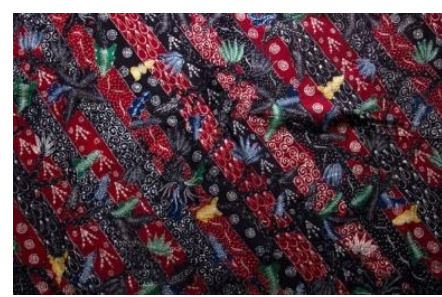

(c)

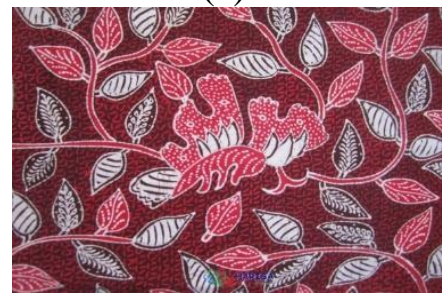

(f)

Gambar 1. Motif Batik

Gambar 1(a) adalah batik motif serat kayu, (b) motif gentongan, (c) motif tanjung bumi, (d) motif bangkalan, (e) motif sederhana, (f) motif sampang. Dalam hal ini, konsep adalah ide abstrak yang dapat digunakan untuk mengklasifikasikan atau menggolongkan sekumpulan obyek (Skemp, 1987). Konsep adalah ide abstrak yang dapat diasimilasikan dan diakomodasikan dengan pengetahuan sehingga dapat 
mengelompokan dan memberikan nama sekumpulan objek. Konsep matematika yang terdapat di motif Batik Madura dapat dimanfaatkan untuk memperkenalkan matematika melalui budaya lokal. Seperti pada Gambar 1. Konsep-konsep matematika yang relevan dengan masing-masing motif batik di klasifikasi dalam Tabel 1.

Tabel 1. Hasil Pemetaan Konsep-konsep Matematika pada Batik Madura

\begin{tabular}{ll}
\hline \multicolumn{1}{c}{ Motif Batik } & \multicolumn{1}{c}{ Konsep Geometri } \\
\hline Serat Kayu & Garis Lengkung \\
Gentongan & Garis Lurus, Belah Ketupat, Sudut \\
Tanjung Bumi & Garis Sejajar \\
Bangkalan & Konsep Kesebangunan, Segitiga \\
Sederhana & Titik, Simetri \\
Sampang & Lingkaran \\
\hline
\end{tabular}

Tabel 1 menunjukkan bahwa terdapat beberapa konsep bangun datar pada Batik Madura yakni belah ketupat pada motif gentongan, lingkaran pada motif sampang, dan segitiga pada motif bangkalan. Jadi, berdasarkan pemetaan konsep-konsep matematika pada Batik Madura, maka bisa ditemukan bahwa konsep matematika yang termuat pada motif batik ada yang dibentuk merujuk pada suatu bidang datar tertentu dan ada pula yang dibentuk berdasarkan unsur-unsur yang ada di bidang datar. Hasil pemetaan tersebut juga ada kesamaan dengan hasil studi Nisa (2020) pada Batik Pamiluto Gresik. Hasil pemetaan konsep-konsep matematika juga ditemui pada motif batik Paoman oleh Sudirman, Son \& Rosyadi (2018), batik Pasedahan Suropati oleh Ulum (2018), di mana motif tersebut juga dimanfaatkan dalam pembelajaran matematika di sekolah dasar. Demikian pula dengan motif batik Indramayu oleh Sudirman, Rosyadi \& Lestari (2017), motif ceplokan batik Yogyakarta oleh Andriani \& Septiani (2020), serta motif batik trusmi Cirebon oleh Karimah, Kusuma \& Noto (2021), yang dimanfaatkan sebagai sumber daya pengetahuan dalam pembelajaran matematika di sekolah menengah.

Model motif dapat dimanfaatkan dalam pembelajaran karena pemahaman terkait konsep bangun datar yang dikaitkan dengan budaya sekitar ini sebenarnya dapat mengkonstruk pemikiran atau pemahaman siswa (Richardo, 2017). Siswa akan lebih mudah memahami bagaimana bentuk-bentuk bangun datar dalam matematika dengan adanya contoh konkret dari motif-motif yang ada pada batik Madura. Hal ini sesuai dengan pendapat Fitroh (2015) bahwa pada Kurikulum 2013 menuntut untuk lebih mengenal budaya sebagai dasar peningkatan kemampuan pemahaman siswa terhadap budaya yang ada di sekitarnya. Selain itu, berdasarkan hasil studi Lydiati (2020) bahwa penggunaan motif batik dapat meningkatkan kemampuan koneksi matematis siswa dengan cara menerapkan konsep-konsep yang diperoleh baik dalam masalah matematika maupun dalam kehidupan nyata terkait suatu motif batik tertentu.

Konsep simetri, kesebangunan, titik, garis, dan sudut juga terdapat pada motif Batik Madura. Konsep simetri ini bisa digunakan sebagai media pembelajaran matematika, dalam hal ini adalah simetri lipat. Siswa dapat memetakan konsep simeri lipat dari beberapa gambar pada motif Batik Madura. Hal ini sejalan dengan Wanita (2014) yang menyatakan bahwa konsep simtri lipat penting dipahami dalam geometri sehingga siswa dapat memanfaatkan motif batik di lingkungan sekitar 
sebagai media pembelajaran. Pemanfataannya dalam hal ini kita dapat belajar bangun-bangun datar dan sisi-sisi dari bangun data itu sendiri, mengenal sudut dan titik serta dua garis sejajar. Dengan demikian pembelajaran matematika di kelas akan lebih bermakna karena hal ini, seperti motif Batik, sudah tidak asing lagi bagi siswa. Siswa tidak hanya memahami dalam bentuk abstraknya saja dan dapat memahami dalam bentuk konkret. Apalagi jika mereka telah mencoba menggambar motif Batik tersebut pada kain. Ini merupakan salah satu cara mengaplikasikan konsep geometri melalui pembuatan batik langsung. Kondisi seperti tersebut berarti pembelajaran matematika yang disesuaikan dengan kekhasan konsep dan perkembangan berpikir siswa serta bagaimana penerapannya dalam kehidupan sehari-hari.

\section{KESIMPULAN}

Berdasarkan hasil penelitian, maka dapat disimpulkan bahwa motif batik madura memiliki pola dan bentuk yang dapat diintegrasikan dalam pembelajaran geometri. Beberapa motif batik madura dapat dijadikan media untuk memperkenalkan konsep geometri sehingga berpotensi mempermudah siswa dalam memahami konsep matematika yang bersifat abstrak seperti garis lurus, garis lengkung, garis sejajar, simetri, titik, sudut, persegi panjang, segitiga, lingkaran, jajargenjang dan konsep kesebangunan. Konsep matematika yang terdapat di motif Batik Madura dapat dimanfaatkan untuk memperkenalkan matematika melalui budaya lokal. Kelas akan lebih bermakna karena hal ini sudah tidak asing lagi bagi siswa, sudah dikenal dan terdapat dalam lingkungan budaya mereka sendiri. Konsep-konsep matematika yang abstrak akan menjadi konkret apabila mereka sudah mengetahui konsep matematika pada motif batik Madura tersebut. Oleh karena itu, rekomendasi yang sesuai adalah bahwa konsep-konsep matematika pada motif Batik Madura ini dapat digunakan media pembelajaran dalam kegaiatan pembelajaran matematika. Selain untuk memudahkan dalam memahami materi geometri, memperkenalkan budaya khas Madura pada siswa akan dapat membangun pengetahuan tentang budaya mereka sendiri.

\section{REFERENSI}

Alghadari, F., \& Son, A. L. (2018). Teori dan kemampuan matematis dalam permainan kartu Gaple: Kajian etnomatematika. Wacana Akademika: Majalah Ilmiah Kependidikan, 2(1), 25-37. https://doi.org/10.30738/wa.v2i1.1984

Andriani, S., \& Septiani, I. (2020). Etnomatematika motif ceplokan batik yogyakarta dalam peningkatan pemahaman konsep matematika siswa. Delta: Jurnal Ilmiah Pendidikan Matematika, 8(1), 81-92. https://doi.org/10.31941/delta.v8i1.966

Arwanto, A. (2017). Eksplorasi etnomatematika batik trusmi Cirebon untuk mengungkap nilai filosofi dan konsep matematis. Phenomenon: Jurnal Pendidikan MIPA, 7(1), 40-49. https://doi.org/10.21580/phen.2017.7.1.1493

Bishop, A. J. (1991). Mathematics education in its cultural context. In M. Harris (ed.). School Mathematics and Work. Academic Press. https://doi.org/10.1007/978-94-017-2209-4_4 
D'Ambrosio, U. (2001). Ethnomathematics. Link Between Traditions and Modernity. Sense Publisher.

Karimah, N. I., Kusuma, D. A., \& Noto, M. S. (2021). Etnomatematika: Analisis Sistem Geometri Pada Motif Batik Trusmi Cirebon. Euclid, 8(1), 16-40.

Lestari, N. T., \& Syafii, S. (2019). Batik Wonogiren: Kajian Proses Pembuatan Dan Motif Di Sentra Batik Tsp Wonogiri. Eduarts: Jurnal Pendidikan Seni, 8(1), 14-23.

Lydiati, I. (2020). Peningkatan Koneksi Matematis Pada Materi Transformasi Geometri Menggunakan Strategi Pembelajaran React Berbantuan Media Motif Batik Kelas XI IPS 1 SMA Negeri 7 Yogyakarta. Ideguru: Jurnal Karya Ilmiah Guru, 5(1), 25-33. https://doi.org/10.51169/ideguru.v5i1.109

Nisa, R. (2020). Eksplorasi Etnomatematika pada Batik Pamiluto Gresik. Briliant: Jurnal Riset dan Konseptual, 5(3), 442-448. https://doi.org/10.28926/briliant.v5i3.462

Prayitno, T. (2020). Mengenal Produk Nasional Batik dan Tenun. Alprin.

Rakhmawati, Y. (2016). Batik Madura: heritage cyberbranding. Jurnal Komunikasi, 10(1), 57-65. https://doi.org/10.21107/ilkom.v10i1.1840

Richardo, R. (2017). Peran ethnomatematika dalam penerapan pembelajaran matematika pada kurikulum 2013. Literasi (Jurnal Ilmu Pendidikan), 7(2), 118125. https://doi.org/10.21927/literasi.2016.7(2).118-125

Rosa, M. \& Orey, D. C. (2011). Ethnomathematics: the cultural aspects of mathematics. Revista Latinoamericana de Etnomatemática, 4(2), 32-54.

Saraswati, H., Iriyanto, E., \& Putri, H. Y. (2021). Batik Banyumasan: Sebagai Identitas Masyarakat Banyumas. LPPM Universitas Negeri Semarang.

Skemp, R. R. (1990). The Psychology ofLearning Mathematics. Lawrence Erlbaum Associates.

Suciaty, N., Dewi, S. S., Nurfadilah, D., \& Santoso, E. (2019). Penerapan etnomatematika motif batik khas majalengka menggunakan konsep geometri transformasi. In Prosiding Seminar Nasional Pendidikan, 281-287.

Sudirman, S., Son., A. L., \& Rosyadi, R. (2018). Penggunaan Etnomatematika pada Batik Paoman dalam Geometri Bidang di Sekolah Dasar. Indonesia $\begin{array}{lll}\text { Mathematics } \quad \text { Education, } & \text { 27-34. }\end{array}$ https://doi.org/10.30738/indomath.v1i1.2093

Sudirman, S., Rosyadi, R., \& Lestari, W. D. (2017). Penggunaan etnomatematika pada karya seni batik Indramayu dalam pembelajaran geometri transformasi. Pedagogy: Jurnal Pendidikan Matematika, 2(1), 74-85.

Suminto, R. S. (2015). Batik Madura: Menilik Ciri Khas dan Makna Filosofinya. Corak: Jurnal Seni Kriya, 4(1), 1-12. https://doi.org/10.24821/corak.v4i1.2356

Ulum, B. (2018). Etnomatematika pasuruan: Eksplorasi geometri untuk sekolah dasar pada motif batik Pasedahan Suropati. Jurnal Review Pendidikan Dasar: Jurnal Kajian Pendidikan dan Hasil Penelitian,4(2), 686-696. https://doi.org/10.26740/jrpd.v4n2.p686-696

Wanita, T. (2014). Developing the Motion of Symmetry Through Batik Exploration. Universitas Negeri Surabaya.

Zayyadi, M. (2017). Eksplorasi Matematika pada Batik Madura. Sigma, 2(2), 3540. 